\title{
Solid Waste Management Awareness and Practices among Senior High School Students in a State College in Zamboanga City, Philippines
}

\author{
Romenick Alejandro Molina ${ }^{1 *}$, Ivee Catan ${ }^{1}$
}

${ }^{1}$ Zamboanga City State Polytechnic College, PHILIPPINES

*Corresponding Author: molina.romenick17@gmail.com

Citation: Molina, R. A.., \& Catan, I. (2021). Solid Waste Management Awareness and Practices among Senior High School Students in a State College in Zamboanga City, Philippines. Aquademia, 5(1), ep21001. https://doi.org/10.21601/aquademia/9579

\section{ARTICLE INFO}

Received: 4 Aug. 2020

Accepted: 27 Oct. 2020

\begin{abstract}
Solid waste management is one of the challenges faced by many countries. Poor solid waste management will lead to various problems in health, environment and socio-economic aspects. Since, educational institution is an agent of change and through R.A. No. 9003, solid waste management concepts are being integrated in science education. In this study, descriptive quantitative approach was utilized using the researcher made instrument - Solid Waste Management Awareness and Practices Questionnaire (SWMAPQ). A total of 332 Grade 12 students participated in the study from a State College, of which 68 are Science, Technology, Engineering and Mathematics (STEM) students, 166 are Technical Vocational Livelihood (TVL) students and 98 are General Academic Strand (GAS) students. Result shows that students have enough knowledge in terms on definition of solid waste, effect of improper solid waste disposal, solid waste prohibited activities, school initiatives towards solid waste, importance of solid waste management and students' responsibilities. However, students have low knowledge on the different laws relevant to solid waste management. Television or radio, parents and social media are the sources of these awareness. The result also shows that students have good solid waste management practices in terms on segregation, reduction, reuse, recycle and disposal.
\end{abstract}

Keywords: assessment, awareness, management, practices, solid waste

\section{INTRODUCTION}

Philippines is an archipelagic country located in the Southeast Asia. It has a dynamic and rapid economy due to increasing urbanization, growing middle class and it has a large and young population (World Bank, 2020). Given this condition, solid waste production in the Philippines also increases (Castillo \& Otoma, 2013). Republic Act No. 9003 (Ecological Solid Waste Management Act of 2000) defined solid waste as all discarded household, commercial waste, non-hazardous institutional and industrial waste, street sweepings, construction debris, agriculture waste, and other non-hazardous/non-toxic solid waste. It is also evident that in other places, solid waste production is increasing. According to World Bank (2019), there will be an increase on waste generation annually all over the globe by $70 \%$ from 2.01 billion tons in 2016 to 3.40 billion tons by 2050. The increase of solid waste generation causes its management more challenging
(Al-Katib et al., 2010). Thus, solid waste management is a must. Solid waste management pertains to the control of generation, storage, collection, transfer and transport, processing, and disposal of solid wastes in a manner that is in accord with the best principles of public health, economics, engineering, conservation, aesthetics, and other environmental considerations, and that is also responsive to public attitudes. However, solid waste management tend to be ignored (Masood, Barlow, \& Wilson, 2009). Improper waste disposal, inefficient waste collection and lack of disposal facilities are some concerns on solid waste management in the Philippines (Matunog \& Awa, 2013; Senate Economic Planning Office, 2017). Due to this, Philippines was considered as world's leading plastic polluters (WWF-Philippines, 2018). In addition, poor management of solid waste may cause health hazards to inhabitants, environmental problems such as water and soil contamination, air pollution and flooding and other socio-economic problem (Abu Qdais, 2007; Sharholy et al., 2008; Senate Economic Planning Office, 2017). 
In response to the challenge, San Juan (2019) revealed that participation of community members on solid waste management program depends on the action taken by their leaders or officials. More so, Al-Katib et al. (2010) emphasized that solid waste management requires technical, political, legal, socio-cultural, environmental, economic factors and available resources. The absence of any of the resources will make solid waste management program failure. Thus, the community members will be unsatisfied (Lad, Chauhan, \& Gole, 2020). Aside from these, mass cooperation and active participation is also necessary. Therefore, educating people through information dissemination on how to handle produced solid waste has become essential (Marello \& Helwege, 2014; Nolasco, Baguia, \& Padua, 2019). Oliva as cited by Villanueva (2013) emphasized that education is one of the four key components to have a good solid waste management program. However, poor information dissemination strategy on solid waste management will make the public less aware and less participative on the program (Nolasco, Baguia, \& Padua, 2019). For instance, Dela Cruz (2020) revealed that in a certain community, solid waste management program is moderately implemented. Thus, section 55 of R.A. No. 9003 mandated Department of Education (DepEd), Commission on Higher Education (CHED) and other national agencies to carry continuing education and information dissemination program on solid waste management. The education and information dissemination should focus on a.) develop public awareness on the ill - effects and community - based solution to the solid waste problem; b.) provide feasible activities which will have greatest impact on solid waste problem; and c.) encourage the public to patronize environmental friendly products. Furthermore, R.A. No. 9512 (Environmental Awareness and Education Act of 2008) requires the mentioned agencies to integrate environmental education in the school curricula at all levels, whether public or private schools. More so, it encourages the tertiary education through National Service Training Program to conduct activities but not limited to tree planting; waste minimization, segregation, recycling and composting; freshwater and marine conservation; forest management and conservation; relevant livelihood opportunities and economic benefits; and other such programs and undertakings to aid the implementation of different environmental protection laws.

Since school is one of the avenue that will provide education and will disseminate information about solid waste management, several studies were conducted in determining its impact in the student's level of awareness and practices. However, these are conducted in tertiary education. For instance, Paghasian (2017) revealed that college students in Maigo has a high level of awareness on solid waste management. Meanwhile, their solid waste management practices in terms of segregation, reduce and recycle were good; while their practices in terms on recycle and disposal were fair. The awareness on solid waste management of the students had no influence on their practices in disposal however had affected their practices specifically on segregation, reduce, reuse, and recycle. In the study of Gequinto (2016), the extent on solid waste management practices among college students from different state universities and colleges in CALABARZON were determined.
Of which, waste collection got the highest composite mean particularly on the promotion of 3Rs (reduce, reuse, recycle) while waste recycling and waste treatment obtained the lowest composite mean.

Meanwhile, solid waste management studies in basic education is limitted and has given less attention. Thus, in this study, senior high school students were utilized. Senior high school curriculum is newly integrated in the basic education, which can be traced back when R.A. No. 10533 or the Enhanced Basic Education of 2013 was enacted. Since the students spend 12 years in basic education with the integration of environmental awareness and education in their curricula, the researcher would like to determine the level of solid waste management awareness among senior high school students, the sources of their awareness and their solid waste management practices.

\section{METHODS}

\section{Research Design}

In facilitating the gathering of data, methods will be used depending on the purpose and scope for which the study was undertaken. The study will utilize descriptive - quantitative approach through the use of Solid Waste Management Awareness and Practices Questionnaire (SWMAPQ) developed by the researchers.

\section{Respondents of the Study}

A total of 332 Grade 12 students participated in the study, of which 68 are Science, Technology, Engineering and Mathematics (STEM) students, 166 are Technical Vocational Livelihood (TVL) students and 98 are General Academic Strand (GAS) students. Respondents were gathered through total enumeration.

\section{Research Instrument}

Solid Waste Management Awareness and Practices Questionnaire (SWMAPQ) was developed by the researchers, patterned from books and existing studies on Solid Waste Management. SWMAPQ is divided into three parts. Part 1 has a total of 36 statements focusing on Solid Waste Management Awareness. More so, part 2 has a total of 10 items that focuses on the sources of Solid Waste Management Awareness among respondents. Lastly, part 3 has a total of 25 items that deals with the Solid Waste Management Practices of the respondents. Pilot testing was carried with non-participating Grade 12 students, and SWMAPQ obtained a Cronbach alpha value of 0.90 , which can be interpreted that the developed instrument has excellent internal consistency (George \& Mallary, 2003).

\section{Data Gathering Procedure}

The researchers secured permission from the State College President and from the senior high school unit Principal. Upon approval, the researchers met the students and distributed the assent and consent form and orient the students on the purpose of the study and their responses on the questionnaire will be treated with utmost confidentiality and will solely be used in the purpose of the study. The researchers met the 
Table 1. Interpretation of SWMAPQ

\begin{tabular}{cccc}
\hline Rate & $\begin{array}{c}\text { Solid Waste Management } \\
\text { Awareness }\end{array}$ & $\begin{array}{c}\text { Sources of Solid Waste } \\
\text { Management Awareness }\end{array}$ & $\begin{array}{c}\text { Solid Waste Management } \\
\text { Practices }\end{array}$ \\
\hline $3.25-4.00$ & Very High (VH) & Very Great Extent (VGE) & Always (A) \\
\hline $2.50-3.24$ & H (High) & Great Extent (GE) & Often (O) \\
\hline $1.75-2.49$ & Low (L) & Less Great Extent (LGE) & Seldom (S) \\
\hline $1.00-1.74$ & Very Low (VL) & Least Great Extent (LtGE) & Never (N) \\
\hline
\end{tabular}

Table 2. Definition of Solid Waste

\begin{tabular}{|c|c|c|c|c|c|c|}
\hline \multirow{2}{*}{ As a Senior High School Student, I am aware of/ on/that } & \multicolumn{2}{|c|}{ STEM } & \multicolumn{2}{|c|}{ GAS } & \multicolumn{2}{|c|}{ TVL } \\
\hline & WM & DR & WM & DR & WM & DR \\
\hline \multicolumn{7}{|l|}{ 1. solid waste are } \\
\hline a. agricultural waste. & 3.19 & $\mathrm{H}$ & 3.10 & $\mathrm{H}$ & 3.18 & $\mathrm{H}$ \\
\hline b. construction debris. & 3.18 & $\mathrm{H}$ & 3.01 & $\mathrm{H}$ & 3.00 & $\mathrm{H}$ \\
\hline c. commercial waste. & 3.24 & $\mathrm{H}$ & 2.86 & $\mathrm{H}$ & 2.95 & $\mathrm{H}$ \\
\hline d. institutional waste. & 2.85 & $\mathrm{H}$ & 2.92 & $\mathrm{H}$ & 2.93 & $\mathrm{H}$ \\
\hline e. street sweepings. & 3.07 & $\mathrm{H}$ & 3.18 & $\mathrm{H}$ & 3.15 & $\mathrm{H}$ \\
\hline f. discarded household. & 3.21 & $\mathrm{H}$ & 3.02 & $\mathrm{H}$ & 2.98 & $\mathrm{H}$ \\
\hline g. non-hazardous industrial waste. & 2.96 & $\mathrm{H}$ & 2.92 & $\mathrm{H}$ & 2.84 & $\mathrm{H}$ \\
\hline $\begin{array}{ll}\text { Composite Mean } \\
\end{array}$ & 3.10 & $\mathbf{H}$ & 3.00 & $\mathbf{H}$ & 3.01 & $\mathbf{H}$ \\
\hline
\end{tabular}

Table 3. Effect of Improper Solid Waste Disposal

\begin{tabular}{|c|c|c|c|c|c|c|}
\hline \multirow{2}{*}{ As a Senior High School Student, I am aware of/ on/that } & \multicolumn{2}{|c|}{ STEM } & \multicolumn{2}{|c|}{ GAS } & \multicolumn{2}{|c|}{ TVL } \\
\hline & WM & DR & WM & DR & WM & DR \\
\hline \multicolumn{7}{|l|}{ 2. improper disposal of solid waste may lead to } \\
\hline a. Clogging of drainage canal that will lead to floods during rainy season & 3.62 & $\mathrm{VH}$ & 3.56 & VH & 3.38 & $\mathrm{VH}$ \\
\hline b. Breeding or shelter of pests such as flies, rats and mosquitos & 3.46 & $\mathrm{VH}$ & 3.33 & $\mathrm{VH}$ & 3.15 & $\mathrm{H}$ \\
\hline c. Human illnesses. & 3.54 & $\mathrm{VH}$ & 3.38 & $\mathrm{VH}$ & 3.28 & $\mathrm{VH}$ \\
\hline d. Degradation or destruction on environment such as a pollution. & 3.51 & $\mathrm{VH}$ & 3.35 & $\mathrm{VH}$ & 3.24 & $\mathrm{H}$ \\
\hline e. Serious treat on animals & 3.44 & $\mathrm{VH}$ & 3.27 & $\mathrm{VH}$ & 3.07 & $\mathrm{H}$ \\
\hline $\begin{array}{l}\text { Composite Mean } \\
\end{array}$ & 3.51 & VH & 3.38 & VH & 3.23 & $\mathbf{H}$ \\
\hline
\end{tabular}

Grade 12 subject teachers and asked for a schedule for the conduct of the study. On the appointment date and time, the researchers collected the assent and consent form per students, and distributed personally the SWMAPQ to the participating students in their classroom. The researchers explained to the students the nature of the checklist. The assessment took only for 15 minutes.

\section{Analysis of Data}

The gathered data were tallied and tabulated. Mean per item was obtained and Mean per competency was computed. The computed mean for both item and competency was interpreted using Table 1.

\section{RESULTS AND DISCUSSION}

\section{Solid Waste Management Awareness}

The level of solid waste management awareness was measured into seven (7) indicators: solid waste definition; effects of solid waste if improperly disposed; relevant laws; prohibited activities; school/ community intervention; importance of solid waste management; and responsibilities of students. Table 2 shows the level of awareness among senior high school students on the definition of solid waste.

As shown in the table, students from STEM, GAS and TVL obtained a composite mean of 3.10, 3.00 and 3.01, respectively.
These indicate that students regardless of strands have average knowledge on what solid waste are. In the study Mishra, Mishra and Tiwari (2014) defined solid waste as useless, unwanted and discarded material resulted from day to day activities from different organizations such as agriculture, construction, commercial, institutions, streets, households and various industries. Knowing the definition of solid waste will help the users to understand the characteristics of the waste. Thus, users can monitor and manage the waste properly to protect human health and environment. (Lamb, Pogson, \& Schlies, 2012).

Table 3 shows the respond of senior high students on their awareness on the possible effect of solid waste if improperly disposed. These effects are serious negative environmental problem such as infectious diseases, land and water pollution, obstruction of drains and loss of biodiversity (Ejaz et al., 2010).

The result revealed that STEM and GAS students have very high awareness with a composite mean of 3.51 and 3.38 respectively. While TVL students obtained a composite mean of 3.23, which can be interpreted as high. It can be noted that TVL students obtained a weighted mean of 3.07 to 3.24 with a descriptive rating of high on the following possible effect: breeding or shelter of pests, destruction on environment and serious treat on animals. Understanding the possible effect of improperly disposed solid waste will make people realized the importance of practicing solid waste management. 
Table 4. Relevant Laws on Solid Waste

\begin{tabular}{|c|c|c|c|c|c|c|}
\hline \multirow{2}{*}{ As a Senior High School Student, I am aware of/ on/that } & \multicolumn{2}{|c|}{ STEM } & \multicolumn{2}{|c|}{ GAS } & \multicolumn{2}{|c|}{ TVL } \\
\hline & WM & DR & WM & DR & WM & DR \\
\hline \multicolumn{7}{|l|}{ 3. different laws or ordinances relevant to solid waste management such as } \\
\hline a. Presidential Decree No. 825 & 2.31 & $\mathrm{~L}$ & 2.47 & $\mathrm{~L}$ & 2.62 & $\mathrm{H}$ \\
\hline b. R.A. No. 9003 & 2.24 & $\mathrm{~L}$ & 2.40 & $\mathrm{~L}$ & 2.48 & $\mathrm{~L}$ \\
\hline c. R.A. No. 8749 & 2.24 & $\mathrm{~L}$ & 2.40 & $\mathrm{~L}$ & 2.54 & $\mathrm{H}$ \\
\hline d. R.A. No. 9275 & 2.35 & $\mathrm{~L}$ & 2.41 & $\mathrm{~L}$ & 2.50 & $\mathrm{H}$ \\
\hline e. Zamboanga City Ordinance No. 500 & 2.38 & $\mathrm{~L}$ & 2.54 & $\mathrm{H}$ & 2.62 & $\mathrm{H}$ \\
\hline Composite Mean & 2.30 & $\mathbf{L}$ & 2.45 & $\mathbf{L}$ & 2.55 & $\mathbf{H}$ \\
\hline
\end{tabular}

Table 5. Solid Waste Prohibited Activities

\begin{tabular}{|c|c|c|c|c|c|c|}
\hline \multirow{2}{*}{ As a Senior High School Student, I am aware of/ on/ that } & \multicolumn{2}{|c|}{ STEM } & \multicolumn{2}{|c|}{ GAS } & \multicolumn{2}{|c|}{ TVL } \\
\hline & WM & DR & WM & DR & WM & DR \\
\hline \multicolumn{7}{|l|}{ 4. Following prohibited activities such as } \\
\hline $\begin{array}{l}\text { a. Littering throwing or dumping of waste in public places such as a roads, } \\
\text { esteros, etc. }\end{array}$ & 3.50 & $\mathrm{VH}$ & 3.38 & VH & 3.17 & $\mathrm{H}$ \\
\hline b. Open burning of leaves and plastics. & 3.47 & $\mathrm{VH}$ & 3.18 & $\mathrm{H}$ & 3.03 & $\mathrm{H}$ \\
\hline c. Open dumping of waste on flood prones areas. & 3.25 & VH & 3.20 & $\mathrm{H}$ & 3.03 & $\mathrm{H}$ \\
\hline d. Mixing of solid waste in any waste box or receptacle & 3.12 & $\mathrm{H}$ & 3.08 & $\mathrm{H}$ & 2.91 & $\mathrm{H}$ \\
\hline $\begin{array}{l}\text { e. Unauthorized removal of recyclable materials from waste box or } \\
\text { receptacle. }\end{array}$ & 3.07 & VH & 3.04 & $\mathrm{H}$ & 2.93 & $\mathrm{H}$ \\
\hline Composite Mean & 3.28 & VH & 3.18 & $\mathbf{H}$ & 3.01 & $\mathbf{H}$ \\
\hline
\end{tabular}

Table 6. School Intervention on Solid Waste

\begin{tabular}{|c|c|c|c|c|c|c|}
\hline \multirow{2}{*}{ As a Senior High School Student, I am aware of/ on/ that } & \multicolumn{2}{|c|}{ STEM } & \multicolumn{2}{|c|}{ GAS } & \multicolumn{2}{|c|}{ TVL } \\
\hline & WM & DR & WM & DR & WM & DR \\
\hline \multicolumn{7}{|l|}{ 5. school initiative such as } \\
\hline a. Having solid waste management program & 3.04 & $\mathrm{H}$ & 3.28 & $\mathrm{H}$ & 3.11 & $\mathrm{H}$ \\
\hline b. Having policies on Solid Waste Management & 2.97 & $\mathrm{H}$ & 3.30 & $\mathrm{H}$ & 3.15 & $\mathrm{H}$ \\
\hline $\begin{array}{l}\text { c. Having sanction on violating the schools or community Solid Waste } \\
\text { Management Policy }\end{array}$ & 2.79 & $\mathrm{H}$ & 3.05 & $\mathrm{H}$ & 2.95 & $\mathrm{H}$ \\
\hline d. Generating funds out of waste & 2.75 & $\mathrm{H}$ & 2.87 & $\mathrm{H}$ & 2.92 & $\mathrm{H}$ \\
\hline $\begin{array}{ll}\text { Composite Mean } \\
\end{array}$ & 2.89 & $\mathbf{H}$ & 3.13 & $\mathbf{H}$ & 3.04 & $\mathbf{H}$ \\
\hline
\end{tabular}

Table 4 shows the respond of the senior high school students on their awareness on different laws relevant on solid waste. Data revealed that STEM and GAS students have low awareness on the different laws with a composite mean of 2.30 and 2.45 respectively. While TVL students have high awareness on the different laws with a composite mean of 2.55.

Article 3 of the Philippine Civil Code highlights the principle "Ignorance of the law excuses no one from compliance therewith". Thus, it is essential that students should know the different laws relevant on solid waste. This further implies that teachers should integrate in their lesson some relevant laws on solid waste management. The National Solid Waste Management Status Report (2008 - 2014) emphasized some relevant laws to include: Presidential Decree No. 825 which provides penalties for improper disposal of garbage and other forms of uncleanliness; R.A. No. 9003 the policy which mandate the state to adopt a systematic, comprehensive and ecological solid waste management program; R.A. No. 8749 which mandate agencies to provide and integrate air quality framework; and R.A. No. 9275 which mandate agencies to protect, preserve and revive fresh, brackish and marine waters. More so, knowing the local ordinance is also essential. In Zamboanga City, City Ordinance No. 500 mandate the separation of various wastes that shall comply with the city's solid waste management program.
Table 5 shows the level of awareness among senior high school students on solid waste prohibited activities. Data revealed that STEM students have very high awareness on prohibited activities with a composite mean of 3.28 . Meanwhile, GAS and TVL students obtained a composite mean of 3.18 and 3.01 which is interpreted as high awareness.

Having very high or high awareness on different prohibited activities is an indicator that students can perform good solid waste management practices, avoid them violating the section 48 of R.A. No. 9003 and prevent them from being penalized with fine or imprisonment. The fine ranges from 500 to 1,000 , 000 Philippine pesos while imprisonment ranges from 15 days to 6 years depending on the prohibited act performed.

Table 6 shows the students' level of awareness in terms on school initiative towards solid waste management. Data shows that STEM, GAS and TVL students obtained a composite mean of $2.89,3.13$ and 3.04 respectively. These can be interpreted that students have high awareness on the school or community solid waste program.

Students have high awareness on the school or community initiative towards solid waste management due to the students' involvement in different school - based or community - based activities such as Loyalty or General Cleaning Day. Teachers played important role in monitoring the implementation of waste management program of the 
Table 7. Importance of Solid Waste Management

\begin{tabular}{|c|c|c|c|c|c|c|}
\hline \multirow{2}{*}{ As a Senior High School Student, I am aware of/ on/ that } & \multicolumn{2}{|c|}{ STEM } & \multicolumn{2}{|c|}{ GAS } & \multicolumn{2}{|c|}{ TVL } \\
\hline & WM & DR & WM & DR & WM & DR \\
\hline \multicolumn{7}{|l|}{ 6. the importance of Solid Waste Management such as } \\
\hline a. key to achieve a clean and green environment. & 3.53 & VH & 3.46 & $\mathrm{VH}$ & 3.21 & $\mathrm{H}$ \\
\hline b. reduce the reproduction of pests. & 3.29 & VH & 3.37 & VH & 3.02 & $\mathrm{H}$ \\
\hline c. protect public health. & 3.47 & $\mathrm{VH}$ & 3.40 & $\mathrm{VH}$ & 3.27 & $\mathrm{VH}$ \\
\hline Composite Mean & 3.43 & VH & 3.41 & VH & 3.17 & $\mathbf{H}$ \\
\hline
\end{tabular}

Table 8. Student's Role and Responsibilities

\begin{tabular}{|c|c|c|c|c|c|c|}
\hline \multirow{2}{*}{ As a Senior High School Student, I am aware of/ on/that } & \multicolumn{2}{|c|}{ STEM } & \multicolumn{2}{|c|}{ GAS } & \multicolumn{2}{|c|}{ TVL } \\
\hline & WM & DR & WM & DR & WM & DR \\
\hline \multicolumn{7}{|l|}{ 7. my role and responsibilities such as } \\
\hline a. reduce the waste generated. & 3.43 & $\mathrm{VH}$ & 3.39 & VH & 3.19 & $\mathrm{H}$ \\
\hline b. clean as you go or CLAYGO. & 3.62 & $\mathrm{VH}$ & 3.46 & VH & 3.21 & $\mathrm{H}$ \\
\hline c. segragate waste when disposing based on the trashcan labels. & 3.50 & $\mathrm{VH}$ & 3.28 & VH & 3.08 & $\mathrm{H}$ \\
\hline d. compost organic waste. & 3.03 & $\mathrm{H}$ & 3.16 & $\mathrm{H}$ & 3.14 & $\mathrm{H}$ \\
\hline e. recycle waste into a new product. & 3.28 & $\mathrm{VH}$ & 3.15 & $\mathrm{H}$ & 3.09 & $\mathrm{H}$ \\
\hline f. refuse single used items. & 3.09 & $\mathrm{H}$ & 3.06 & $\mathrm{H}$ & 2.96 & $\mathrm{H}$ \\
\hline g. reuse items. & 3.10 & $\mathrm{H}$ & 3.18 & $\mathrm{H}$ & 3.03 & $\mathrm{H}$ \\
\hline Composite Mean & 3.29 & VH & 3.24 & $\mathbf{H}$ & 3.10 & $\mathbf{H}$ \\
\hline
\end{tabular}

Table 9. Sources of Solid Waste Management Awareness

\begin{tabular}{|c|c|c|c|c|c|c|}
\hline $\begin{array}{c}\text { I became aware towards Solid Waste Management } \\
\text { because of }\end{array}$ & STEM & GAS & TVL & WM & DR & Rank \\
\hline 1. Television or Radio & 3.32 & 3.55 & 3.35 & 3.41 & VGE & 1 \\
\hline 2. Newspapers or Magazines & 2.85 & 2.96 & 3.11 & 2.97 & GE & 9 \\
\hline 3. School's Orientation or Campaign & 2.94 & 3.33 & 3.07 & 3.11 & GE & 5 \\
\hline 4. Teacher's Discussion & 3.18 & 3.26 & 3.23 & 3.22 & GE & 4 \\
\hline 5. Seminar Workshop & 2.65 & 2.80 & 2.88 & 2.77 & GE & 10 \\
\hline 6. Books & 2.99 & 3.09 & 3.02 & 3.03 & GE & 6 \\
\hline 7. Peers or Classmates & 3.04 & 2.95 & 2.99 & 2.99 & GE & 7 \\
\hline 8. Parents & 3.41 & 3.40 & 3.30 & 3.37 & VGE & 2 \\
\hline 9. Research Articles & 2.91 & 2.92 & 3.12 & 2.98 & GE & 8 \\
\hline 10. Social Media (e.g. facebook, twitter) & 3.26 & 3.42 & 3.20 & 3.29 & VGE & 3 \\
\hline
\end{tabular}

institution. Hence, Punongbayan et al. (2014) pointed out that faculty are promoters and leaders in the implementation of solid waste management program. In addition, intense information dissemination were carried through the efforts of Student Government officials.

Table 7 shows the students' solid waste management awareness in terms on its importance. Data shows that STEM and GAS students have very high awareness on the importance of solid waste management with a composite mean of 3.43 and 3.41, respectively. Meanwhile, TVL students have high aware with a composite mean of 3.17 .

As noticed, STEM and GAS students are very aware on the importance of solid waste management because they have more science subjects compared to TVL students. Nonetheless, being fully aware and moderately aware is an indicator that the respondents can serve as an agent for the success implementation of solid waste management program.

Table 8 shows the students' solid waste management awareness in terms on their role and responsibilities in the implementation of the program. Data revealed that STEM students have very high awareness with a composite mean of 3.29. Meanwhile, GAS and TVL students have high awareness with a composite mean of 3.24 and 3.10 , respectively.
The result indicates that students are knowledgeable on their responsibilities for the success of the solid waste management program. This assessment shows that the respondents in this study is more aware than the respondents in the study of Paghasian (2017). Students are completely aware on their responsibilities because they are knowledgeable on the importance of solid waste management. More so, Lad, Chauhan and Gole (2020) revealed that on this stage, students are ready to help and overcome the different problems associated with solid waste management.

\section{Sources of Solid Waste Management Awareness}

Since information dissemination is essential in the success of the implementation of solid waste management, Table 9 shows the sources of the awareness.

Results shows that the listed sources are important in raising solid waste management awareness. Among these, television or radio obtained the highest mean of 3.41 with descriptive rating of very great extent. Thus, this finding denotes that television and radio has great influence compared to other possible sources. This claim was supported by Dela Cruz (2020), that the seldom use of radio or television affects the awareness of the public. More so, these findings coincide with the study Tubon as cited by Batara (2019). 
Table 10. Segregation of Solid Waste

\begin{tabular}{|c|c|c|c|c|c|c|}
\hline \multirow{2}{*}{ I practice solid waste management by } & \multicolumn{2}{|c|}{ STEM } & \multicolumn{2}{|c|}{ GAS } & \multicolumn{2}{|c|}{ TVL } \\
\hline & WM & DR & WM & DR & WM & DR \\
\hline \multicolumn{7}{|l|}{ 1. segregating waste based on/ which are } \\
\hline $\begin{array}{l}\text { a. Biodegradable (e.g. Papers, leaves, vegetable) from non-biodegradable } \\
\text { (e.g. Plastics, wires, cans). }\end{array}$ & 3.35 & A & 3.33 & A & 3.33 & A \\
\hline $\begin{array}{l}\text { b. Recyclable (e.g. Papers, plastic bottles, cans) from non-recyclable (e.g. } \\
\text { Food waste, leaves). }\end{array}$ & 3.21 & $\mathrm{O}$ & 3.25 & A & 3.20 & $\mathrm{O}$ \\
\hline c. Non-harmful waste from toxic wastes (e.g. Battery, ink, pentel pen). & 3.07 & $\mathrm{O}$ & 2.94 & $\mathrm{O}$ & 3.13 & $\mathrm{O}$ \\
\hline Composite Mean & 3.21 & 0 & 3.17 & 0 & 3.22 & 0 \\
\hline
\end{tabular}

Table 11. Reduction of Solid Waste

\begin{tabular}{|c|c|c|c|c|c|c|}
\hline \multirow{2}{*}{ I practice solid waste management by } & \multicolumn{2}{|c|}{ STEM } & \multicolumn{2}{|c|}{ GAS } & \multicolumn{2}{|c|}{ TVL } \\
\hline & WM & DR & WM & DR & WM & DR \\
\hline \multicolumn{7}{|l|}{ 2. reducing waste by } \\
\hline a. Buying in bulk & 2.87 & $\mathrm{O}$ & 2.92 & $\mathrm{O}$ & 2.89 & $\mathrm{O}$ \\
\hline b. Using ecobag & 3.18 & $\mathrm{O}$ & 3.08 & $\mathrm{O}$ & 3.02 & $\mathrm{O}$ \\
\hline c. Using reusable items rather than single use items. & 3.04 & $\mathrm{O}$ & 2.90 & $\mathrm{O}$ & 2.98 & $\mathrm{O}$ \\
\hline d. Saying no to plastic if only have few items bought & 2.91 & $\mathrm{O}$ & 2.88 & $\mathrm{O}$ & 2.90 & $\mathrm{O}$ \\
\hline e. Prettering items with less packaging. & 3.06 & $\mathrm{O}$ & 2.97 & $\mathrm{O}$ & 2.96 & $\mathrm{O}$ \\
\hline f. Taking lunch in schools using reusable container. & 3.25 & $\mathrm{O}$ & 3.14 & $\mathrm{O}$ & 3.09 & $\mathrm{O}$ \\
\hline g. Converting food waste into animal feed. & 3.10 & $\mathrm{O}$ & 2.95 & $\mathrm{O}$ & 3.01 & $\mathrm{O}$ \\
\hline h. Repairing broken furniture or appliances. & 3.04 & $\mathrm{O}$ & 2.85 & $\mathrm{O}$ & 2.94 & $\mathrm{O}$ \\
\hline i. Buying important items only. & 3.09 & $\mathrm{O}$ & 3.11 & $\mathrm{O}$ & 3.07 & $\mathrm{O}$ \\
\hline Composite Mean & 3.06 & $\mathbf{O}$ & 2.98 & $\mathbf{0}$ & 2.99 & $\mathbf{0}$ \\
\hline
\end{tabular}

Table 12. Reuse of Solid Waste

\begin{tabular}{|c|c|c|c|c|c|c|}
\hline \multirow{2}{*}{ I practice solid waste management by } & \multicolumn{2}{|c|}{ STEM } & \multicolumn{2}{|c|}{ GAS } & \multicolumn{2}{|c|}{ TVL } \\
\hline & WM & DR & WM & DR & WM & DR \\
\hline \multicolumn{7}{|l|}{ 3. reusing items such as } \\
\hline a. scrap papers as memo or scratch for solving & 3.34 & A & 3.20 & $\mathrm{O}$ & 3.18 & $\mathrm{O}$ \\
\hline b. compostable waste is converted into fertilizer. & 3.06 & $\mathrm{O}$ & 2.90 & $\mathrm{O}$ & 3.03 & $\mathrm{O}$ \\
\hline c. washable food and water containers & 3.35 & A & 3.17 & $\mathrm{O}$ & 3.08 & $\mathrm{O}$ \\
\hline d. grocery bags. & 3.15 & $\mathrm{O}$ & 3.21 & $\mathrm{O}$ & 3.10 & $\mathrm{O}$ \\
\hline $\begin{array}{l}\text { e. intact and unused clothes and toys are given to the less fortunate or } \\
\text { orphanage. }\end{array}$ & 3.25 & A & 3.13 & $\mathrm{O}$ & 2.99 & $\mathrm{O}$ \\
\hline Composite Mean & 3.23 & $\mathbf{0}$ & 3.12 & $\mathbf{0}$ & 3.07 & $\mathbf{0}$ \\
\hline
\end{tabular}

Parents was rank as second, as source of solid waste management awareness with a mean of 3.37 . Hence, family is the first school where students learn what is right and what is wrong. Meanwhile, social media ranked third, as source of solid waste management awareness with a mean of 3.29. Social media became one of the factors because it connects people from different places and allow to convey information freely.

Seminar workshop on solid waste management was rank 10 among the listed sources with a mean of 2.77. This is due that, seminar workshops were rarely being conducted. Hence, this kind of activity requires time preparation and budget.

\section{Solid Waste Management Practices}

Gaining students support and involvement promotes solid waste management practices. These practices include waste segregation, reduction, reuse, recycle and disposal. Table 10 shows the solid waste management practices among students in terms of segregation. Segregation as defined in Article 2, Sec. 3 of R.A. No. 9003, pertains to the process of separating materials from the origin in order to facilitate recycling, reuse of materials and reduce waste generation.

Data shows that STEM, GAS and TVL students obtained a composite mean of $3.21,3.17$ and 3.22 , respectively. These indicate that students perform segregation often. The result further indicates that students have good segregation practices. As noticed, students always separate biodegradable and non-biodegradable waste before disposal.

Table 11 shows the solid waste management practices among students in terms of reduction. Reduction is the most prefer ways in solid waste management. Doing reduction saves natural resources, reduces toxicity of waste and reduces costs (The Asia Foundation, 2008).

Data shows that STEM, GAS and TVL students obtained a composite mean of $3.06,2.98$ and 2.99 , respectively, with a descriptive rating of often. Thus, the result further implies that students have good practices in terms on solid waste reduction. Reduction practices among students include the use of reusable container, ecobag and buying important things only.

Table 12 shows the solid waste management practices among students in terms of reuse. Reuse as defined in Article 2, Sec. 3 of R.A. No. 9003 pertains to the recovering of materials that have the same or different usage without changing its physical and chemical characteristics. 
Table 13. Recycle of Solid Waste

\begin{tabular}{|c|c|c|c|c|c|c|}
\hline \multirow{2}{*}{ I practice solid waste management by } & \multicolumn{2}{|c|}{ STEM } & \multicolumn{2}{|c|}{ GAS } & \multicolumn{2}{|c|}{ TVL } \\
\hline & WM & DR & WM & DR & WM & DR \\
\hline \multicolumn{7}{|l|}{ 4. recycling items by } \\
\hline a. converting old items into new products. & 3.09 & $\mathrm{O}$ & 3.11 & $\mathrm{O}$ & 3.05 & $\mathrm{O}$ \\
\hline b. generating funds out from plastic bottles, metals or cans. & 2.90 & $\mathrm{O}$ & 2.81 & $\mathrm{O}$ & 2.93 & $\mathrm{O}$ \\
\hline c. creating art craft. & 2.94 & $\mathrm{O}$ & 2.84 & $\mathrm{O}$ & 3.12 & $\mathrm{O}$ \\
\hline Composite Mean & 2.98 & $\mathbf{0}$ & 2.92 & $\mathbf{0}$ & 3.03 & $\mathbf{0}$ \\
\hline
\end{tabular}

Table 14. Disposal of Solid Waste

\begin{tabular}{|c|c|c|c|c|c|c|}
\hline \multirow{2}{*}{ I practice solid waste management by } & \multicolumn{2}{|c|}{ STEM } & \multicolumn{2}{|c|}{ GAS } & \multicolumn{2}{|c|}{ TVL } \\
\hline & WM & DR & WM & DR & WM & DR \\
\hline \multicolumn{7}{|l|}{ 5. disposing } \\
\hline a. biodegradable items in compost pit. & 3.19 & $\mathrm{O}$ & 3.08 & $\mathrm{O}$ & 3.05 & $\mathrm{O}$ \\
\hline b. items in proper trash bins. & 3.37 & $\mathrm{~A}$ & 3.24 & $\mathrm{O}$ & 3.14 & $\mathrm{O}$ \\
\hline c. waste materials in common open dumps. & 2.99 & $\mathrm{O}$ & 3.03 & $\mathrm{O}$ & 3.02 & $\mathrm{O}$ \\
\hline d. non-biodegradable items by selling it in junkshop. & 3.01 & $\mathrm{O}$ & 2.95 & $\mathrm{O}$ & 3.02 & $\mathrm{O}$ \\
\hline $\begin{array}{l}\text { e. special waste (e.g. Laboratory waste) are disposed in a garbage } \\
\text { container intended for special waste. }\end{array}$ & 3.00 & $\mathrm{O}$ & 3.04 & $\mathrm{O}$ & 2.98 & $\mathrm{O}$ \\
\hline $\begin{aligned} \text { Composite Mean } \\
\end{aligned}$ & 3.11 & $\mathbf{0}$ & 3.07 & $\mathbf{0}$ & 3.04 & $\mathbf{0}$ \\
\hline
\end{tabular}

Data shows that STEM, GAS and TVL students obtained a composite mean of $3.23,3.12$ and 3.07 , respectively with a descriptive rating of often. The result further implies that students have good solid waste management practices in terms on reuse. Some of the practices include the use of scrap papers for solving in mathematics class and washing of food and water containers.

Table 13 shows the solid waste management practices among students in terms of recycling. Recycling as defined in Article 2, Sec. 3 of R.A. No. 9003 pertains to the treating of waste material by converting them into a new product.

Data shows that STEM, GAS and TVL students obtained a composite mean of $2.98,2.92$ and 3.03 , respectively with a descriptive rating of often. The result implies that students have good solid waste management practices in terms on recycle. For instance, students always convert old items into a new products.

Table 14 shows the solid waste management practices among students in terms of disposal. Disposal as defined in Article 2, Sec. 3 of R.A. No. 9003 pertains to the discharge of solid waste.

As noticed, STEM, GAS and TVL students obtained a composite mean of $3.11,3.07$ and 3.04 , respectively with descriptive rating of often. The result implies that students have good disposal practices. For instance, students are always throwing disposable items properly in trash bins.

\section{CONCLUSION}

This study presents the solid waste management awareness and practices among senior high school students in a state college. Results revealed that students have enough knowledge in terms on definition of solid waste, effect of improper solid waste disposal, solid waste prohibited activities, school initiatives towards solid waste, importance of solid waste management and students' responsibilities. However, students have low knowledge on the different laws relevant to solid waste management. These findings suggest that schools and other concerned organizations should conduct intense information dissemination on laws relevant to solid waste management.

The level of awareness on solid waste management can be attributed on the following: television or radio, parents and social media. This finding suggests that the government can utilize these platforms to disseminate intensely solid waste management information.

The result also revealed that students have good solid waste management practices in terms on segregation, reduction, reuse, recycle and disposal.

\section{REFERENCES}

Abu Qdais, H. (2007). Techno-economic assessment of municipal solid waste management in Jordan. Waste Management, 27(11), 1666-1672. https://doi.org/10.1016/ j.wasman.2006.08.004

Al-Khatib, I. A., Monou, M., Abu Zahra, A. S., Shaheen, H. Q., \& Kassinos, D. (2010). Solid Waste Characterization, Quantification and Management Practices in Developing Countries. A Case Study: Nablus District - Palestine. Journal of Environmental Management, 91(5), 1131-1138. https://doi.org/10.1016/j.jenvman.2010.01.003

Batara, O. (2019). Solid Waste Management Program: A Basis for Action Plan of Sta. Catalina, Ilocos Sur, Philippines. Asia Pacific Journal of Multidisciplinary Research, 7(4), 4250. Retrieved from http://www.apjmr.com/APJMR-20197.04.02.06

Castillo, A. and Otoma, S. (2013). Status of Solid Waste Management in the Philippines. Retrieved from https://www.jstage.jst.go.jp/article/jsmcwm/24/0/24_677/_ article 
Dela Cruz, J. (2020). Local Government Unit - Academe Partnership in the Implementation of Solid Waste Management Program in the Philippines. Asia Pacific Journal of Multidisciplinary Research, 8(2). 150-157. Retrieved from http://www.apjmr.com/APJMR-2020.8.2.18

DENR - EMB. (2015). National Solid Waste Management Status Report (2008 - 2014). Retrieved from https://ns wmc.emb.gov.ph/wp-content/uploads/2016/06/SolidWastefinaldraft-12.29.15.pdf

Ejaz, N., et al. (2010). Environmental Impacts of Improper Solid Waste Management in Developing Countries: A Case Study of Rawalpindi City. WIT Transactions on Ecology and the Environment, 142, 379-387. https://doi.org/10.2495/SW100351

George, D. and Mallary, P. (2003). SPSS for Windows Step by Step: A Simple Guide and Reference. 11.0 Update ( ${ }^{\text {th }}$ Ed.). Boston: Ally and Bacon.

Gequinto, A. (2017). Solid Waste Management Practices of Select State Universities in CALABARZON, Philippines. Asia Pacific Journal of Multidisciplinary Research, 5(1), 1-8. Retrieved from http://www.apjmr.com/APJMR-2017.5.1.01

Lad, D., Chauhan, R. and Gole, P. (2020). A Study on Solid Waste Management Awareness Amongst Youngster of Mumbai. EPRA International Journal of Multidisciplinary Research, 6(3), 116-119. https://doi.org/10.36713/epra4115

Lamb, G., Pogson, S. and Schliebs, D. (2012). Waste Definitions and Classifications: Reports on Issues, Opportunities and Information Gaps. North Sydney, Australia: Hyder Consulting Pty Ltd.

Marello, M. and Helwege, A. (2017). Solid Waste Management and Social Inclusion of Wastepickers: Opportunities and Challenges. Latin American Perspectives, 45(1), 108-129. https://doi.org/10.1177\%2F0094582X17726083

Masood, M., Barlow, C., and Wilson, D. (2014). An Assessment of the Current Municipal Solid Waste Management System in Lahore, Pakistan. Waste Management and Research, 32(9), 834-847.https://doi.org/10.1177/0734242X14545373

Matunog, V. and Awa, A. (2013). Solid Waste Generation Rate in Ozamiz City, Philippines. Journal of Multidisciplinary Studies, 1(1), 73-92. https://doi.org/10.7828/jmds.v2i1.396

Mishra A., Mishra, S. and Tiwari, A. (2014). Solid Waste Management - Case Study. International Journal of Research in Advent Technology, 2(1), 396-399. https://www.researchgate.net/publication/262523386

Nolasco, M., Beguia, Y. and Padua, ML. (2019). Solid Waste Management in Naga City: Its Culture of Information Dissemination. Asia Pacific Journal of Multidisciplinary Research, 7(4), 12-17. Retrieved from http://www.apjmr. com/APJMR-2019.7.04.02
Paghasian, M. (2017). Awareness and Practices on Solid Waste Management among College Students in Mindanao State University Maigo School of Arts and Trades. Advances in Social Science, Education and Humanities Research, 128, 5-12. https://doi.org/10.2991/icet-17.2017.2

Punongbayan, C. et al. (2014). Waste Management Practices of an Educational Institution. Asia Pacific Journal of Education, Arts and Sciences. 1(4), 15-120. Retrieved from https://www.researchgate.net/publication/257728721

Republic Act No. 9003. The Ecological Solid Waste Management Act of 2000. Retrieved from https://emb.gov. ph/wp-content/uploads/2015/09/RA-9003.pdf

Republic Act No. 9512. Environmental Awareness and Education Act of 2008. Retrieved from https://www.senate.gov.ph/republic_acts/ra\%209512.pdf

San Juan, F. (2019). Community Participation in Solid Waste Management Program of Selected Community Associations in Zamboanga City, Philippines. Asia Pacific Journal of Multidisciplinary Research, 7(4), 42-49. http://www.apjmr.com/APJMR-2019.7.04.06

Senate Economic Planning Office. (2017). Philippine Solid Waste - At A Glance. Retrieved from https://www.senate. gov.ph/publications/SEPO/AAG_Philippine\%20Solid\%20 Wastes_Nov2017.pdf

Sharholy, M., Ahmad, K., Mahmood, G. and Trivedi, R. (2008). Municipal Solid Waste Management in Indian Cities - A Review. Waste Management, 28(2), 459-467. https://doi.org/10.1016/j.wasman.2007.02.008

The Asia Foundation. (2008). Solid Waste Reduction. Retrieved from https://asiafoundation.org/resources/pdfs/06Solid WasteReduction.pdf

Villanueva, R. (2013). Proper Solid Waste Management: Education, Engineering, Enterprise and Enforcement. Retrieved from https://www.philstar.com/business/ science-and-environment/2013/01/03/892576/propersolid-waste-management-education-engineeringenterprise-and-enforcement

World Bank. (2019). Solid Waste Management. Retrieved from https:/www.worldbank.org/en/topic/urbandevelopment/b rief/solid-waste-management

World Bank. (2020). The World Bank in the Philippines. Retrieved from https://www.worldbank.org/en/country/ philippines/overview

WWF-Philippines. (2018). The Scourge of Single - Use Plastic in the Philippines. https://wwf.panda.org/knowledge_hub/ where_we_work/coraltriangle/?329831/The-scourge-ofsingle-use-plastic-in-the-Philippines 